\title{
Opportunities to Write: An Exploration of Student Writing During Language Arts Lessons in Norwegian Lower Secondary Classrooms
}

Written Communication 2018, Vol. 35(2) II9-154 (C) 2018 SAGE Publications Reprints and permissions: sagepub.com/journalsPermissions.nav DOI: $10.1177 / 0741088317751123$ journals.sagepub.com/home/wcx (9) SAGE (c) (1) \&

\section{Marte Blikstad-Balas', Astrid Roe', and Kirsti Klette ${ }^{\prime}$}

\begin{abstract}
Research suggests that student development as writers requires a supportive environment in which they receive sustained opportunities to write. However, writing researchers in general know relatively little about the actual writing opportunities embedded in students' language arts lessons and how students' production of texts in class is framed. The present study analyzes 178 video-recorded language arts lessons across 46 secondary classrooms in Norway based on the Protocol for Language Arts Teaching Observation. Specifically, we assess how often and in what situations students get an opportunity to engage in writing or are explicitly encouraged to write. We found that some writing assignments are short and fragmented, especially when students are merely recopying information from teachers' materials. However, our analysis also provides detailed insight into how some teachers facilitate sustained, genre-focused, and processoriented writing opportunities. These are powerful examples of successful writing instruction, and they suggest that when Norwegian language arts
\end{abstract}

\footnotetext{
'Department of Teacher Education and School Research, University of Oslo, Blindern, Oslo, Norway
}

\section{Corresponding Author:}

Marte Blikstad-Balas, Department of Education and School Research, University of Oslo, Postboks 1099, Blindern, Oslo 0317, Norway.

Email: marte.blikstad-balas@ils.uio.no 
teachers prioritize writing, the opportunities to write are both sustained and scaffolded, the purpose of writing is explicit, and genre-specific assessment criteria are often used.

\section{Keywords}

writing instruction, sustained writing, video analyses, writing assignments

Active participation in all aspects of today's society requires writing: We write more than ever before, for different audiences, for different purposes, in different genres, and with an increasing variety of writing tools (Brockmeier \& Olson, 2009; Kwok, Ganding, Hull, \& Moje, 2016; UNESCO, 2004; Yi, 2010). Writing is a constant requirement in both personal and professional life, as we consistently engage in textually mediated communication. Even in occupations not traditionally associated with writing, researchers have found that substantial writing requirements are embedded in everyday work life (Beaufort, 2008; Joly, 2010; Karlsson, 2009; Mikulecky, 1998; Smagorinsky \& Mayer, 2014). Writing mediates our access to each other and to society.

The increasingly strong need for complex writing ability leads to high expectations on school systems to develop this competence. Across countries, writing is considered a key aspect of education and a matter of considerable concern; writing is repeatedly identified in research as an aspect of education that many students have a range of difficulties with (Dockrell, 2009; Johannessen \& McCann, 2009; Langer, 2009; MacArthur, Graham, \& Fitzgerald, 2016). Among known factors influencing how students develop as writers are how writing is taught and what opportunities students have to write. In their recent examination of reviews on evidence-based best-practice writing instruction, Graham, Harris, and Chambers (2016) identified a cluster of evidence-based practices that strongly support the importance of actually engaging students during the writing process. Their foremost recommendation was for teachers to provide dedicated time for students to write and for writing instruction to better involve students in various forms of writing over time. While it seems self-evident that to become better writers students must practice writing, little is known about what opportunities students in general have to engage in sustained writing during classroom instruction and how that time is spent. There is a need for systematic investigation not only of the processes of writing and students' written products but also of the amount of dedicated time students have in class to engage in writing and, even more importantly, what kind of writing that takes place when such opportunities are provided. 
This article contributes to research on how writing is taught and framed in classroom settings, by providing systematic, detailed insight into student writing opportunities across a large number of language arts (LA) lessons in lower secondary classrooms in Norway. Opportunities to write are identified as a prerequisite for improving students' writing (Graham et al., 2016; Graham \& Perin, 2007), especially if these opportunities are combined with relevant instructional and thinking strategies and possibilities for student interaction (Cohen \& Grossman, 2016; Johannessen \& McCann, 2009; Smagorinsky \& Mayer, 2014). Several scholars have argued that there is a need for more research-based knowledge about how students actually engage in in-class writing, particularly at the lower secondary level (Kiuhara, Graham, \& Hawken, 2009; Kwok et al., 2016; Olson, 2008). Here, we have systematically investigated "naturally occurring instruction" (Hassan et al., 2005), as opposed to researcher-manipulated interventions that specifically prompt writing. Investigating writing in Norway is particularly interesting as writing has been explicitly defined as a "key competence" in the national curriculum, a competence that should permeate all subjects at all levels. Also, there has been extensive use of process writing since the mid-1980s and more lately an emphasis on writing across the disciplines, which again makes it very interesting to investigate systematically how teachers and students engage in different writing activities (Krogh, Dysthe, Hertzberg, \& Brorsson, 2017). In contrast to many previous studies, our study is not based on surveys of teacher-reported assignments or evaluations of final student writing products; rather, it is based on video recordings of actual instruction across 46 LA classrooms (four consecutive lessons in each classroom). Thus, our main analytical focus is on how teachers frame writing and engage students in writing activities rather than on the actual texts written by students. This approach aims to provide new, nuanced insight into how writing is taught, into the different discourses of writing in the classroom, and into students' opportunities to practice sustained writing during their lessons.

\section{The Norwegian Context}

All Norwegian children have a legal right to 13 years of free education. Schooling starts at 6 years. The school system is divided into primary (Grades 1-7), lower secondary (Grades 8-10), and upper secondary school (Grades 11-13). This article focuses on students in their first year of lower secondary school (Grade 8, ages 13-14). Norwegian LA is the mother tongue subject (L1) in Norway and is also the subject with the largest number of lessons, with approximately five lessons per week throughout secondary school. The subject is not systematically divided into, for example, reading, writing, word 
work, and so on (as is typical in many American classrooms), but takes place as a regular block at each school. The length of lessons may vary (most are 45 minutes, some are 60, and some schools have multiple lessons in the same subject consecutively).

At the end of lower secondary school, an exam preparation day is provided during which students are provided in advance with the topic they are going to write about and relevant texts they may use in their writing. These exams prioritize extended writing (Hertzberg \& Roe, 2015). As Sigmund Ongstad (2002) describes, Norway has a long tradition of instruction that emphasizes this type of writing: Students are expected in their exam to write several pages of typed text over as much as 5 hours, choosing between several writing tasks. The exam is supposed to give a broad measure of writing competence. Further, teachers tend to prepare their students for these exams through "writing days" or "pseudo-exams" with assignments that resemble the actual exam. These extensive writing exams have dominated the focus of writing research in Norway; it is difficult to find Norwegian research on writing that is not related to these very specific writing situations (Ongstad, 2002). Thus, investigation of students' everyday writing opportunities, not directly related to these exams, is crucial. To understand how students are developing as writers and practicing specific features of genres and taskspecific writing (Smagorinsky \& Smith, 1992), we must look at what happens before the final evaluations.

\section{What Do We Know About Writing Instruction in Lower Secondary School?}

The following review of research on the kinds of writing students are doing in school serves as an important backdrop for our investigation of writing opportunities. We also highlight key factors associated with good teaching of writing in a school context.

Although writing activities are associated with most school subjects, many studies suggest that generally, students do not have many opportunities to engage in composing texts for more than a few minutes at a time (Applebee, 1984; Applebee \& Langer, 2009, 2011a, 2011b; Gillespie, Graham, Kiuhara, \& Hebert, 2014; Kiuhara et al., 2009). The extensive National Study of Writing Instruction investigated American students' writing assignments across different subjects in middle and high school (Applebee \& Langer, 2006, 2009, 2011a, 2011b). Among key findings, even though students wrote more in English than in any other subject, they were generally not writing a great deal. Among 8,542 texts gathered 
from 138 students over a semester, only $19 \%$ of the assignments required extended writing of a paragraph or more. The majority of student-written texts were short answers to exercises, fill-in-the-blanks assignments, or recopying information from teachers' presentations. When comparing their findings to a similar study from 1979 to 1980, Applebee and Langer emphasized that although students are writing more in all subjects, the writing they are doing is short. Students are seldom given opportunities to "use composing as a way to think through issues, to show the depth or breadth of their knowledge, or to go beyond what they know in making connections and raising new issues" (Applebee \& Langer, 2011a, p. 16). In a survey of how American lower secondary teachers teach writing, Kiuhara et al. (2009) found that across subjects (including LA) an extensive amount of student writing is what they label "writing without composing," for example, filling in worksheets, making lists, and writing short answers. The four most common writing activities (used at least once a week by most teachers) were writing short answers (typically for homework), responding to material read, completing worksheets, and summarizing material. Thus, most writing done by students does not require actual composition, nor does it require substantial analysis or interpretation (Kiuhara et al., 2009).

Studies show that, particularly in American classrooms, writing generally serves limited functions. For instance, it is often used to reproduce content in a small number of specific genres and less frequently used to foster reasoning and exploration of ideas (Boscolo \& Carotti, 2003; Boscolo \& Hidi, 2007; Wade \& Moje, 2000). Boscolo and Hidi (2007) explain how instructional conceptualization of writing often limits students' ability to use writing as a communicative tool because they seldom have an awareness of how writing can be a "powerful tool for fixing, using, changing and re-elaborating their ideas and knowledge" (p. 4) or for collaboration both inside and outside the classroom.

In Norway, where the present study's empirical data were collected, the situation appears similar in terms of writing across subjects. An extensive study of writing instruction (Smidt, 2010), excluding pseudo-exams, identified fragmentation as a feature of writing across subjects and grades, that is, many small assignments, with weak links between them. While teachers seem to have a clear purpose behind writing assignments, their students seem unaware of why they are writing different texts and assume that the teacher is their only audience (Smidt, 2010). In Norwegian LA lessons, however, several studies clearly indicate that writing has a different character, especially because of the extensive writing students must produce for exams (Smidt, 2007). 
Additional studies provide valuable insight about the type of writing instruction that fosters student development as writers; many suggest that students develop their writing skills by engaging in sustained and systematic writing. In a review of previous research on what characterizes successful writing instruction, Graham et al. (2016) suggest that supportive writing environments are crucial. Research on effective writing instruction highlights the importance of discussing and planning texts, involving students in writing over time, and teaching writing strategies (Bazerman, 2016; Gadd \& Parr, 2017; Graham et al., 2016; Kiuhara et al., 2009; Smagorinsky \& Mayer, 2014).

In the United States, the National Writing Project (NWP), since the 1970s a forerunner in process writing, currently offers professional development programs and frequent, ongoing opportunities for teachers to examine theory, research, and practice together systematically. In 16 studies conducted in seven states, 103 of 112 comparisons show positive results in writing achievement favoring students in classrooms of NWP participants. In every case, the improvement of students taught by teachers who participated in NWP programs exceeded that of students whose teachers were not participants (Kaminski, Hunt-Barron, Hawkins, \& Williams, 2010). Teaching struggling students relevant strategies for planning, revising, and editing their text is particularly powerful (Graham \& Perin, 2007). Further, explicating expected textual norms has a positive effect on student writing (Berge \& Skar, 2015; Matre \& Solheim, 2015). In Norway, making the purposes of writing more visible has been emphasized, particularly when it comes to the purposes of the different stages in the writing process.

Process writing, which focuses on the writing process itself, in addition to the final written product, holds a strong position among teachers of Norwegian LA. In 1985, it was introduced to a group of teachers and teacher educators by researchers from the Bay Area Writing Project. The course was very popular and resulted in a grassroots movement that in a few years spread to LA teachers throughout Norway. Process writing was included in the national curriculum in 1997 and eventually became part of teacher education. In addition to the phases of prewriting, drafting, responding, and editing, process writing in Norway has been supplemented with structured scaffolding and explicit teaching of genres and text types (Hertzberg \& Dysthe, 2012). Although the term "process writing" is less commonly used now, a 2013 survey of 218 LA teachers in Norwegian lower secondary schools suggests that process writing has become part of most LA teachers' practice. Two thirds of teachers reported that they included elements of process writing in their writing instruction, and $96 \%$ reported that they responded to or scaffolded their students' learning to varying degrees during the writing process 
(Roe \& Helstad, 2014). Recent studies show Norwegian teachers use a process-oriented approach to teaching writing (C. Jensen, 2016), with emphasis on genre, purpose, and intended audience (L. V. Jensen, 2016).

\section{Theoretical Perspectives on Writing in a School Context}

This article's premise - that students benefit from in-school writing opportunities, and not, for instance, solely from homework-based writing assignments or everyday writing outside of school-is closely linked to a sociocultural perspective on learning and writing. Informed by this perspective, we understand writing as a social activity, always embedded in broader social practices. This view is well described elsewhere (e.g., Alvermann, 2009; Barton, 1991, 2007; Bazerman, 2016; Kwok et al., 2016), so rather than elaborate on its foundations, we emphasize the aspects of sociocultural theories most relevant to the research presented here. A key premise of sociocultural theories is that writing is a form of participation in discourses and is facilitated by interaction with a more knowledgeable other. Written language learning depends on a range of explicit teaching practices and scaffolding in relevant ways of using writing (Kwok et al., 2016). While we acknowledge that writing practices may be developed outside of school (Gee, 2015; Hull \& Schultz, 2001; MacGillivray \& Curwen, 2007; Yi, 2010), our primary concern here is the teaching of writing taking place within a school context and, thus, the social practices of writing associated with the school domain. Extensive research exists on how children learn to read and write (both in and out of school), and on the specific texts they write, but globally there is less research about what kind of writing practices students are engaging in at school and what roles writing actually plays in everyday lessons in the classroom context.

In this article, we are concerned with all writing activities, which we define, here, as empirically observable activities in which writing is undertaken. Through their writing assignments and activities, both oral and written, teachers foreground what they consider to be important in regard to writing. In contrast to studies focusing on texts produced by students, our main aim is to explore how often and in what situations students get an opportunity to engage in writing or are explicitly encouraged to write. Utilizing a large data set, we systematically examine the opportunities students get to write, and the types of writing in which they engage. As described in the methods section, we draw on the Protocol for Language Arts Teaching Observation (hereafter PLATO), an observation manual explicitly grounded in a sociocultural view of learning (see Grossman et al., 2013), to identify 
situations in which students are producing texts. In particular, the PLATO manual's emphasis on instructional scaffolding through teacher modeling, explicit teaching of ELA strategies, and guided practice resonates well with a sociocultural view of learning (Klette \& Blikstad-Balas, 2017). Further, it aligns with seminal research on effective instruction in LA in general and writing in particular (Bazerman, 2016; Graham et al., 2016).

\section{Research Design and Method}

This study is part of the large-scale video study Linking Instruction and Student Achievement, funded by the Research Council of Norway. ${ }^{1}$ During the 2014-2015 school year, our research team (including several research assistants) collected data from 46 different eighth-grade LA classrooms (13- to 14-year-old students) across Norway. These classrooms are hereafter referred to by school number. Four consecutive lessons in each class were video-recorded, totaling 178 lessons. We also collected copies of assignments given to students. The schools were sampled to include a demographic and geographic spread and various levels of student achievement (based on high and low gains on national reading tests). The teachers included in the study vary in age and years of teaching experience. A majority of the participating teachers are female, but this also reflects the overall gender imbalance among teachers of lower secondary school LA. Further, the amount of professional development courses attended by teachers varies. We believe the sample reflects the range of Norwegian LA teachers. Written and informed participation consent was provided by parents, students, and teachers.

\section{Video Recordings of Lessons}

Video recordings are valuable in classroom analysis due to the possibility of systematically investigating complex educational settings and deconstructing in detail qualities in teaching (Blikstad-Balas, 2017; Heath, Hindmarsh, \& Luff, 2010; Klette, 2009; Snell, 2011). In the present study, via video analyses we tracked how much time students spent writing in general and analyzed in detail the writing situations students and teachers engaged in across lessons. The video design relied on two cameras simultaneously recording the same lesson: one capturing the class and one focusing on the teacher (see Figure 1). We used two microphones, one placed on the teacher and one fixed to capture the class. This provided reasonably good audio of both whole-class discourse and teacher interactions with one or a few students at a time. Both situations are important when investigating opportunities to write, as some 


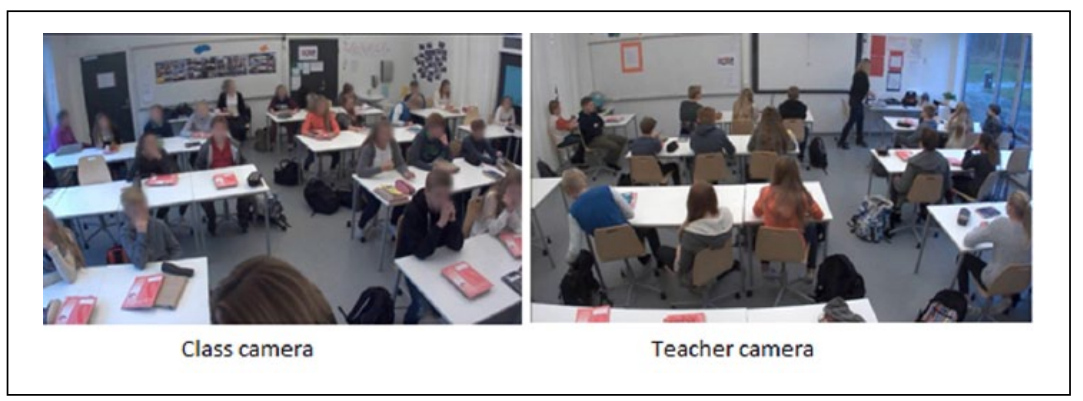

Figure I. Camera views.

instruction happens in a whole-class scenario, while additional guidance is commonly provided to one or a few students by teachers walking around.

\section{Analyses Using the Protocol for Language Arts Teaching Observation Manual}

We obtained a systematic overview of the 178 LA lessons using the PLATO observation instrument developed by Grossman and Colleagues (2013). PLATO is a particularly relevant tool for the present study as it is tailored to assess specific aspects of instruction related to LA. It focuses on 13 elements of instruction that are highlighted in existing literature on adolescent literacy and effective instruction in secondary LA education. In essence, the theory underlying PLATO articulates the importance of rigorous content and intellectually challenging tasks, the centrality of classroom discussion in developing sophisticated understanding of content and disciplinary skills, and the critical role of teachers in providing instructional scaffolding for students to help them succeed (Cohen \& Grossman, 2016, p. 310).

Among the elements of PLATO, one is of particular importance to the present study, namely, "text-based instruction," including the subcategory "production of texts," a category developed to describe how often students are "given the opportunity to engage in the writing process and work on producing texts for an extended period of time" (PLATO 5.0). We used this subcategory in analyzing the collected material to obtain a systematic overview of the degree to which students have opportunities to write.

Each recorded lesson was divided into 15-minute segments $(N=541)$; these were coded by at least one certified PLATO rater. Depending on the amount of evidence of student writing or writing instruction during each 15-minute cycle, raters assessed the opportunities to write using a four-point 


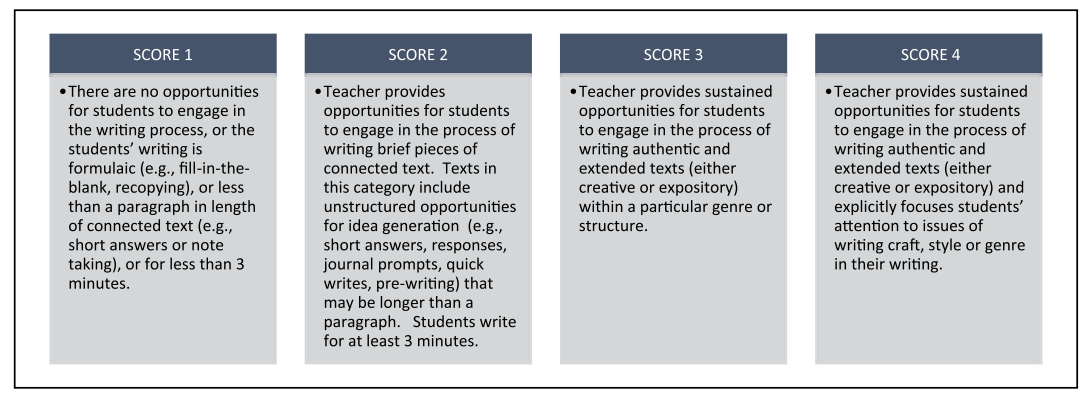

Figure 2. Overview of the categories describing production of text (PLATO 5.0).

scale. Scores of 1 and 2 indicate no or little evidence of instructional practice in which students are producing texts. Scores of 3 or 4 indicate that the lessons are characterized by evidence with some weaknesses or strong and consistent evidence, respectively, that the teacher is providing instructional activities that require students to actively produce texts for a sustained period of time. The key considerations when coding a segment relate to what kind of writing students are doing (for example, we distinguish between fill-in-the blank assignments, passive note taking, and actual composition of new text), length of written text, duration of writing activity, and attention to craft. A random selection of 77 segments (15\%) were coded by two different coders to measure interrater reliability. For the subcategory "production of texts," pairs of coders gave identical codes to 65 segments (84\%), and disagreement exceeded one point in just one segment. Figure 2 provides an overview of the scoring in the subcategory "production of texts" from PLATO (Grossman, 2010; Grossman et al., 2013).

Authentic text, in this case, refers to student-generated work that is at least a complete paragraph, in line with PLATO's description. "Sustained" applies to writing or writing instruction lasting more than 7 minutes of the 15 -minute segment, and "brief" opportunities refer to at least 3 minutes of writing. The term "extended text" refers to texts that are connected (for example, through multiple paragraphs in an essay, or lines that are supposed to be read sequentially in a poem), in contrast to, for example, multiple disconnected short answers to different questions. Extended texts should be at least a paragraph in length.

Video provides an opportunity to study in detail how reading and writing actually happen in a given context (Blikstad-Balas, 2017; Blikstad-Balas \& Sørvik, 2015). In addition to assigning a PLATO score for each 15-minute segment, we conducted qualitative video analyses using InterAct software to 
identify what kind of writing activities are typical within each score and how these are framed by the teacher. Further, we identified typical examples of the different writing activities and transcribed these to provide illustrative examples in our analyses. Although we do not analyze student texts in the present study, we have included some examples of student writing embedded in different activities to give a fuller picture of what the writing activities and writing processes actually entailed.

A possible limitation of the present study is that the design will typically not capture writing that happens when teachers decide to separate writing time from ordinary instruction, for example, by having a "writing day." Further, some teachers may prefer "traditional teaching" in a whole-class setting rather than letting students write for lengthy periods when their instruction is being video-recorded. This assumption was reinforced by a teacher who thought we were coming a day later than we did during our data collection period; the teacher had planned for students to write during the whole lesson, which she did not think we were interested in recording. As the present study is concerned with what kind of writing opportunities students engage in during ordinary instruction, we believe our design still provides very useful data, especially as we follow each teacher through four consecutive lessons. Further, studies have shown that effective writing teachers are often able to combine writing with other domains of LA, embedding writing assignments in instruction, for instance, by combining talking and writing (Grossman et al., 2013).

\section{Results: What Types of Writing Activities Are Students Engaging In?}

Table 1 illustrates how often students were given opportunities to engage in different kinds of text production across each 15-minute segment of the 178 lessons, using the categories described in Figure 2.

Critically, $85 \%$ of the segments contain no opportunities to engage in sustained writing, scoring either 1 or 2 on "production of texts." Across classrooms, a majority of the segments scoring 1 were segments in which there was no writing. The one activity we do find frequently that includes writing and still is defined as 1 in "production of texts" is note taking. In contrast to studies in upper secondary school suggesting that note taking is a voluntary and individual activity (Blikstad-Balas, 2012; Brevik, 2017), these students were sometimes directly asked to write down specific phrases, tasks, or words. These notes were often kept in a subject-specific notebook, and teachers often guided the note-taking process by signaling where and how notes 
Table I. Overview of Opportunities to Write Indicated by PLATO Scores $(N=54 I)$.

\begin{tabular}{lcccc}
\hline & Score I & Score 2 & Score 3 & Score 4 \\
\hline $\begin{array}{l}\text { Number of 15-minute } \\
\text { segments at this level }\end{array}$ & 382 & 76 & 59 & 24 \\
Percentage & 70.6 & 14.1 & 10.9 & 4.4 \\
\hline
\end{tabular}

should be written. Notes and note taking can be demanding writing tasks, requiring analysis and active engagement. In our data, however, lower secondary school teachers usually wrote everything the students should write on the blackboard or Smartboard, so students were not "taking notes" by summarizing teachers' verbal speech or selecting important points; rather, these writing activities consisted of recopying everything the teacher wrote. When teachers used PowerPoint presentations, students were also often told what to write and how:

Teacher (School 4): Then you can write that the date today is [DATE]. And then, as a heading, you can write "Tips for writing a dialogue." Then comes the aim of the lesson after today's date [reads from the board]: "I understand how I can describe thoughts and dialogues well." [Repeats it.] Those who are done can think about why we use dialogue in a narrative text. Think about that while we wait for the others to finish writing.

Such note taking does not require students to compose their own sentences; thus, these segments are all scored as no opportunity to produce texts.

The $70 \%$ of segments identified as no opportunity to produce texts suggests that very little writing is taking place. It is important to remember, however, that we have analyzed not just writing lessons but all kinds of LA lessons, which may include oral presentations, silent reading, or teaching of subject areas other than writing. Still, we found that 24 of the 46 classes did have at least one opportunity to engage in sustained writing during the four lessons we recorded, which is somewhat more promising.

The most interesting segments for our further analyses are the ones in which students are producing text of some kind (segments scoring 2 [15\%], 3 [11\%], and $4[4 \%])$. In the following analyses, we provide examples of the types of student writing identified as typical writing activities across all 178 lessons, as well as giving nuanced descriptions of how these writing activities are typically framed. We will make a distinction between what we label "short writing activities" (scoring 2 in PLATO) and "sustained writing activities" (scoring 3 or 4). Although the PLATO manual measures quality and 
distinguishes between low-end and high-end scores, writing activities should be considered in context. For example, it is very common for the same writing lesson to score both 3 and 4 over the three segments making up a single 45-minute lesson. As they tend to appear together, we do not make a strong distinction between activities scoring 3 and 4 . Further, we have identified a number of writing activities that are of high quality (and largely fit the criteria for activities scored 3 and 4) but are assigned a 2 based on the limited duration of the activity. As many of the teachers have a process-oriented approach to writing, it is not uncommon that writing activities scoring 2 in one lesson are referred back to or used as a starting point for sustained writing (scoring 3 or 4 ) in the following lesson. As we also illustrate writing activities scoring 2 should not automatically be considered low-quality writing instruction, as they may be targeting writing for a brief period of time.

\section{Short Writing Activities}

Many teachers gave students the opportunity to write brief, connected texts in their lessons. These activities can be divided into two main categories: writing as a tool to communicate content knowledge and prewriting activities within specific genres.

In Norway, writing is used in all subjects to demonstrate students' content knowledge. Even in subjects typically not associated with writing (e.g., music or physical education), writing is defined as a key competence, and across the curriculum student assessment often includes students writing to express their knowledge and reflection about specific topics. This is also a common purpose of writing in the observed LA lessons. Typically, the emphasis in these tasks is not the actual writing; rather, it is on whether students have mastered specific content. Thus, writing in these activities functions as a way to document knowledge or to mediate communication between teachers and students, and between students. A good example of such writing is from School 10, where a lesson about the Nordic languages concluded with the task depicted in Figure 3.

Here, writing was used to show students' mastery of other content, in this case, knowledge about the Nordic languages. Another example of writing to show content knowledge in LA is from School 42, where students used a graphic organizer to show their knowledge about literature from different periods. The organizer (Figure 4) had six prompts: "This is what I remember about the Renaissance," "This is what I remember about the Reformation," "This is what I remember about the Baroque and psalms," "This is what I remember about the Enlightenment," "Ludvig Holberg (Norwegian writer)," and "This is what I know so far about Erasmus Montanus (a play)." Here, the 


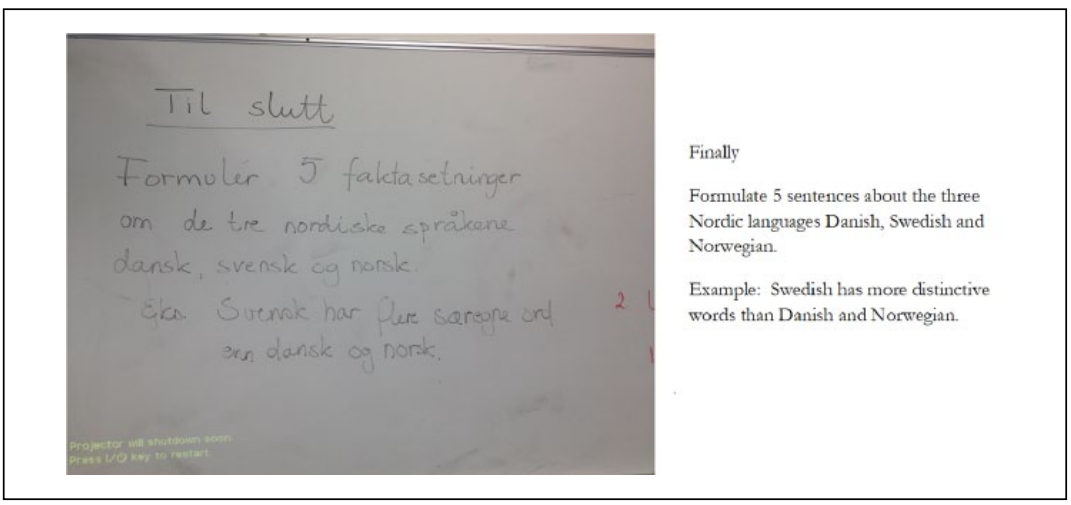

Figure 3. Students are asked to write five sentences to demonstrate content knowledge.

writing was not connected to subsequent longer writing tasks; rather, students spent a whole class session talking about and to some degree justifying what they had written as answers to the six prompts.

In many classrooms, students were also asked to write short logs, where the purpose of writing was to communicate with the teacher about their learning. For example, some teachers finished their lessons by requesting that students write a brief evaluation of that particular lesson. These assignments involved only a few minutes of writing at the end of the lesson. In some cases, the evaluation was directly tied to the lesson's specific learning goals:

Teacher (School 2): What was the learning goal of the lesson? See if you can remember it. Did you learn something new? ... Does anyone need a sheet of paper? Write your name at the top. I want to see what you got out of this and whether I'm totally on the wrong track.

These writing assignments can be seen in relation to the significant emphasis Norway places on assessing learning pedagogy, wherein students are expected to be given clear learning goals and assess what they have learned during a specific lesson (Brevik, Blikstad-Balas \& Engelien, 2016; Gamlem, 2017).

\section{Prewriting Within Specific Genres}

The other main type of short writing activities is intended to develop students' writing abilities. Typical examples include planning texts, working on 


\begin{tabular}{|c|c|c|}
\hline 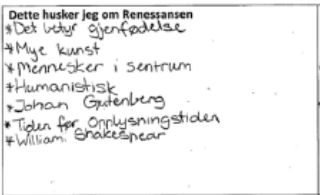 & 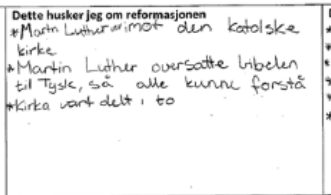 & 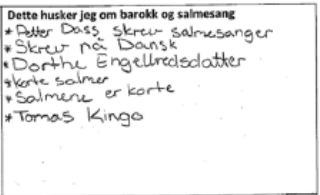 \\
\hline 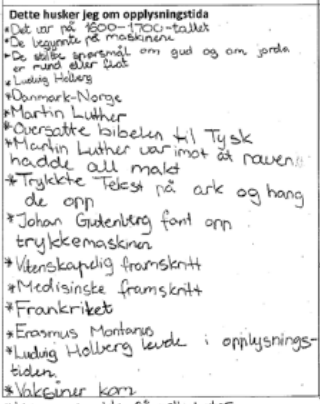 & 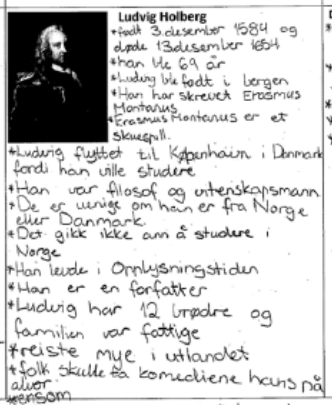 & 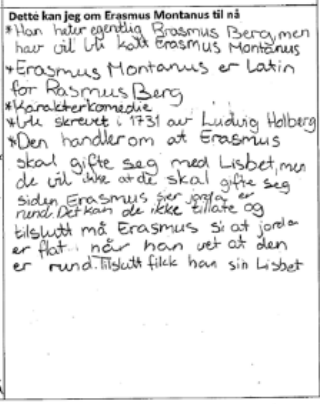 \\
\hline 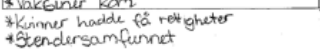 & *Hansom skrew jerpe nà benget og & \\
\hline
\end{tabular}

\begin{tabular}{|c|c|c|}
\hline $\begin{array}{l}\text { This is what I remember about the } \\
\text { Renaissance } \\
\text { * It means rebirth } \\
\text { *A lot of art } \\
\text { * Human -centered } \\
\text { * Johan Gutenberg } \\
\text { * The period before the Enlightenment } \\
\text { * William Shakespear (sic) }\end{array}$ & $\begin{array}{l}\text { This is what I remember about the } \\
\text { Reformation } \\
\text { "Martin Luther against the catholic } \\
\text { church } \\
\text { "Martin Luther translated the bible to } \\
\text { German, so everyone could understand } \\
\text { "The church was divided in two }\end{array}$ & $\begin{array}{l}\text { This is what I remember about the baroque } \\
\text { and psalms } \\
\text { * Petter Dass wrote psalms } \\
\text { * wrote in Danish } \\
\text { *Dorothe Engelbrettsdottir [Norwegian writer] } \\
\text { *Short psalms } \\
\text { "Tormas Kingo [Norwegian writer] }\end{array}$ \\
\hline $\begin{array}{l}\text { This is what I remember about the } \\
\text { Enlightenment } \\
\text { *It was in the } 1600-1700 \\
\text { *They started the machines } \\
\text { "They questioned god and whether the } \\
\text { Earth was round or flat } \\
\text { "Ludvig Holberg } \\
\text { *Martin Luther } \\
\text { "Translated the bible to German } \\
\text { *Martin Luther was against the Pope } \\
\text { having all the power } \\
\text { *Printed test on paper and displayed it } \\
\text { *Johan Gutenberg invented the printing } \\
\text { press } \\
\text { *Scientific progress } \\
\text { *Medical progress } \\
\text { *France } \\
\text { "Erasmus Montanus [Norwegian play] } \\
\text { * Lndvig Holberg lived during the } \\
\text { enlightenment } \\
\text { *The vaccines } \\
\text { *Women had few rights } \\
\text { *Hierarchic society }\end{array}$ & $\begin{array}{l}\text { Ludvig Holberg } \\
\text { "Born on December the 3rd } 1584 \text { and } \\
\text { died on December the 13th } 1654 \\
\text { "He was } 69 \text { years old } \\
\text { "Ludvig was born in Bergen } \\
\text { "He wrote Erasmus Montanus } \\
\text { "Erasmus Montanus is a play } \\
\text { "Ludvig moved to Copenhagen to } \\
\text { study } \\
\text { "He was a philosopher and a scientist } \\
\text { "There is a disagreement on whether he } \\
\text { is from Norway or Denmark } \\
\text { "It was not possible to study in Norway } \\
\text { "He lived during the enlightenment } \\
\text { "He is a writer } \\
\text { "Ludvig had } 12 \text { brothers and the family } \\
\text { was poor } \\
\text { "Traveled a lot abroad } \\
\text { "People were supposed to take his } \\
\text { comedies seriously } \\
\text { "He wrote "Jeppe pa berget" and } \\
\text { "Niles Klim" }\end{array}$ & $\begin{array}{l}\text { This is what I know so far about Erasmus } \\
\text { Montanus } \\
\text { "His name was really Rasmus Berg, but he wants } \\
\text { to be called Erasmus Montanus } \\
\text { "Erasmus Montanus is Latin for Rasmus Berg } \\
\text { "A character comedy } \\
\text { "Was written in } 1731 \text { by Ludvig Holberg } \\
\text { "It is about Erasmus Montanus who is going to } \\
\text { marry Lisbeth, but they don't' want them to get } \\
\text { married because Erasmus says the Earth is round. } \\
\text { That cannot be allowed, and in the end Erasmus } \\
\text { has to say that the Earth is flat when he knows it } \\
\text { is round. In the end he got his Lisbeth. }\end{array}$ \\
\hline
\end{tabular}

Figure 4. Graphic organizer showing content knowledge about different literary periods.

specific writing elements, such as "show don't tell," and developing arguments as prewriting for a future persuasive essay. Our qualitative analyses 


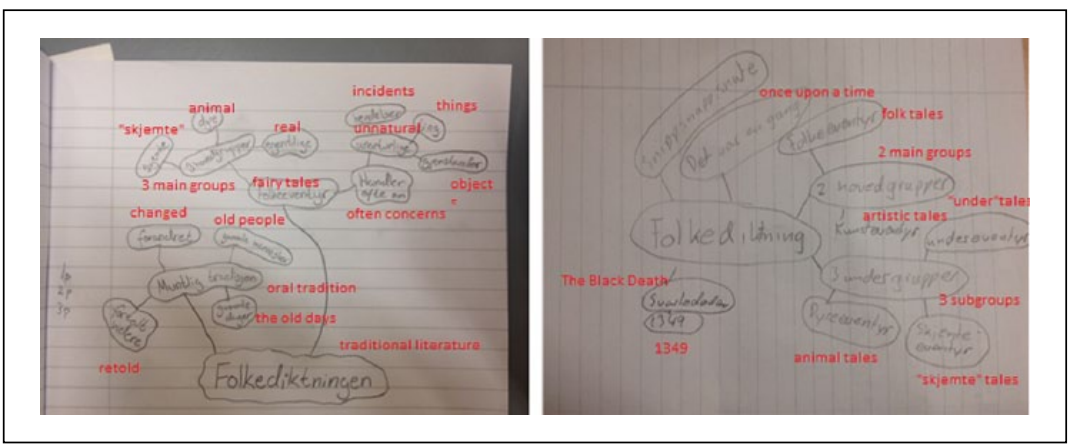

Figure 5. Mind maps showing students' individual work with traditional literature and the fairy tale genre.

show that a majority of teachers who provide writing instruction do so in accordance with a process discourse and a genre discourse of writing (Ivanič, 2004), which we will return to when analyzing sustained writing opportunities. Many of the smaller writing assignments these teachers gave prior to production of longer texts were scored as limited opportunities to write (score 2), although it was systematic writing instruction that later led to longer texts. For example, students we observed in School 33 were tasked with writing a fairy tale. First, they made mind maps about the typical genre features of traditional literature (see Figure 5). They initially worked alone and were told to think back to prior instruction and see what they could remember about the genre.

Then, students worked in groups of four or five. The youngest student in each group started a new mind map with what he or she remembered about traditional literature and then passed the sheet to another student. After all students had contributed, the teacher challenged the groups to collaborate on each other's original points, and to see which group could make the most detailed account of the genre.

In the next lesson, students continued to work on fairy tale as a genre, using a graphic organizer to plot their own fairy tale (see Figure 6).

The teacher in School 33 used several smaller writing tasks to scaffold students into the fairy tale genre. This is not uncommon in our material. Across the lessons we observed, we found that in several lessons emphasizing fiction, the students were asked to write short descriptive texts in which they were supposed to show and not tell. For example, in School 40, students had to choose a small object at home and bring it to school. Then, over several small assignments, they described the object in as much detail 


\section{Planning the start}

Draw and describe the characters

in your fairy tale / Write a good sentence to start your story / What problem needs to be solved?/ What mission does the hero have?

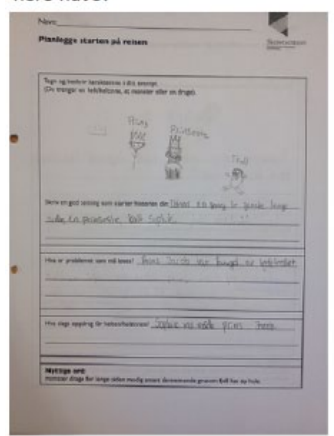

Useful words: monster, dragon, "a long, long time a go", brave, smart, scary, cruel, mountain, ocean, island, cave
Planning the main part

Draw and describe the jourey the hero must do to fulfill the mission/ Draw and describe the place where the monster/creature lives

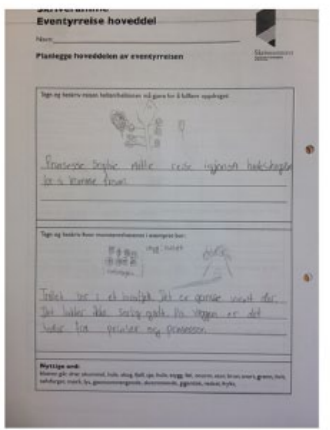

Useful words: climbs, walks, leaves, scary, forest, mountain, sea, ugly, bad, enormous, huge, brown, black, green, white, silver, dark, light, (...)
Planning the ending

Draw and describe what happens when the hero meets the monster / Write the final sentence in your story

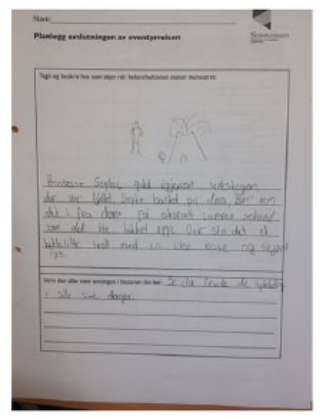

Figure 6. Graphic organizer for planning a fairy tale.

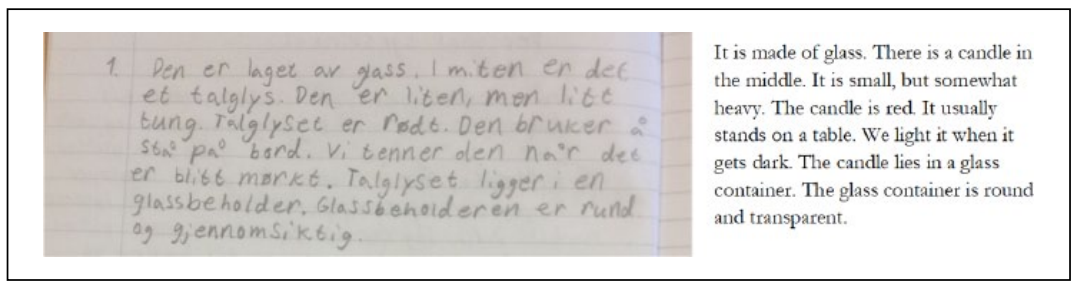

Figure 7. Student text, detailed description I.

as they could, in preparation for writing a good short story later. First, the students were given the following short task: "Find your object. Find your pencil and write down the very first thought or associations you get when you look at your object." A student who brought a candlestick wrote the text in Figure 7.

Next, students were given a new assignment: "Now you are going to describe the object as thoroughly as you can. Think about all the details about the object. After that, you are going to describe what the object is used for." 


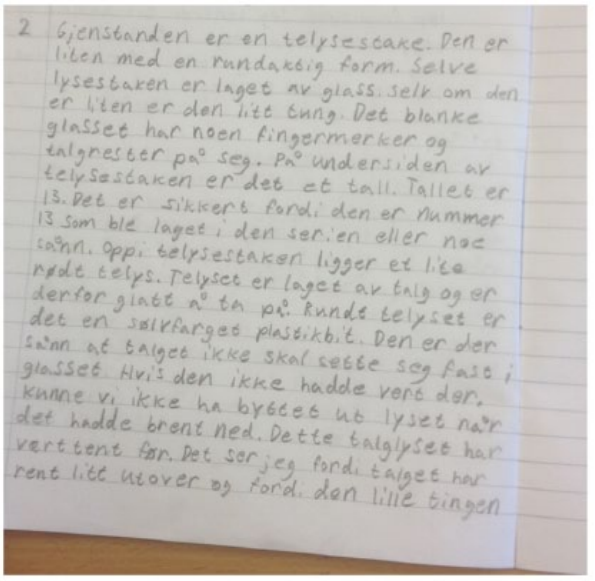

(New page)

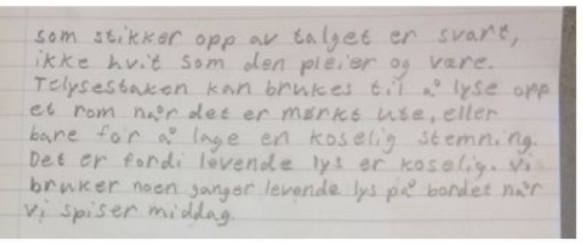

The object is a candle stick: It is small with a circular shape. The stick itself is made of glass, and although it is small, it is rather heavy. The clear glass has some finger marks and tallow on it. Under the candle stick there is a number. The number is 13 . That is probably because it is number 13 of the ones that were made in this series or something like that. Inside the candle stick there is a small red candle. It is made of tallow and therefore it is smooth to touch. Around the candle there is a silvery plastic piece. It is there to prevent the tallow from sticking to the glass. If it weren't there we couldn't have changed the candle when it had burnt down. This candle has been lit before, I can see that because the tallow has been melted and because the little thing that sticks up from the tallow is black and not white as it usually is. The candle stick can be used to lighten up a room when it is dark outside, or just to create a cozy atmosphere. That is because candles are cozy. We sometimes use candles on the table when we have dinner.

Figure 8. Student text, detailed description 2.

There was no decisive time limit and students could write for over 5 minutes. The student who brought the candle stick now wrote the text in Figure 8.

Across lessons, students were provided with other short writing tasks, where the aim was to improve their abilities to describe well, which is a prerequisite for writing good stories in general and short stories in particular.

\section{Sustained Writing Activities}

When students were asked to write for sustained periods of time, the writing was often connected to a specific genre, a given writing style, or specific ways of writing associated with specific techniques. These lessons $(n=33)^{2}$ all contain writing activities scored as level 3 or 4 production of text precisely because there is an expectation of writing within a given structure, style, craft, or genre and the writing continues for more than 7 consecutive minutes. Table 2 provides an overview of the types of writing students were asked to 
Table 2. Overview of Lessons with Writing Events Scoring 3 and 4.

School and

(lesson)

Short description of writing assignment

2 (2) Students are writing short stories. In this lesson they are revising their texts based on their teacher's written feedback.

3 (I) Students are going to write a story, and start out with a creative writing assignment where they have to imagine a scenario and describe it in detail.

9 (3) Students are working on a writing technique labeled "expanding the moment," by writing as detailed as they can about a particular event.

$12^{*}(\mathrm{I}-2) \quad$ Students are working on book reports about a novel read by the entire class, with specific criteria regarding tone, style, and content of the report.

13* (2) Teacher spends majority of lesson prompting students for adjectives and metaphors describing how someone acts and looks when they are sad, angry, happy, or afraid, generating an extensive list on the board; students then write a paragraph-long detailed description of a person feeling one of the four feelings, using "show, don't tell."

$13(3-4) \quad$ Students are going to write stories, and in this lesson they use a graphic organizer ("a content star" to plan the plot of their stories). They get feedback on their plot and start writing the introduction of their story.

I4 (4) Students are writing a letter to the editor. The teacher explains how they are going to provide feedback for each other in response groups in the next lessons. (This was the last lesson we recorded in School 14.)

I5 (I) Students are writing descriptive texts. They write two different introductions, one with a first-person point of view, and one with a third-person point of view.

$17^{*}(2) \quad$ Students are practicing different reading strategies and ways to annotate texts; teacher discusses keywords, topic sentences, and ways to identify difficult words; students practice these writing strategies with different short texts.

22 (2) Students work with stories with no details, and try to improve them by elaborating and "expanding the moment" techniques they have learned in a previous lessons.

24 (3) Students get a text where the main character is a 3-year-old.

They are asked to continue writing the story and are specifically encouraged to keep the same initial writing style, reflecting that the first-person narrator is a child. They have to "think like a child" and write accordingly. 
Table 2. (continued)

School and

(lesson)

Short description of writing assignment

$25^{*}(1-2) \quad$ Students are working on how to write good descriptions in narratives (textbook assignment): Describe current situation in as much detail as possible. "Describe the room you are sitting in. Imagine that you enter the door. What do you see? What do you hear? How does the room seem to you? Write one page."

27 (I) Students are writing the introduction to short "mock articles," and use examples from their textbooks as models.

27 (2) (Continuation of previous lesson) The students keep writing their "mock articles," with explicit emphasis on relevant language and terminology.

$27^{*}(3-4) \quad$ Students are writing short "mock articles," focusing on style rather than content, with the goal of expressing their content in a precise and accurate way and choosing words and phrases that fit well with the article genre; students select the topic.

28* (I) Teacher uses "letter to the editor" as a model text to discuss how to persuade with arguments and influence the reader; students write a letter to the editor in an engaging and argumentative way, collaborating and providing feedback to each other, while teacher provides individual guidance.

28* (2) (Continuation of previous lesson) Students continue working with their texts with the goal of finishing the main part; teacher provides collective instruction on how to check whether an argument is convincing; students continue writing for about 15 minutes, then discuss their texts in response groups; during writing time, teacher provides individual guidance.

28 (3) (Continuation of previous lesson) Students work on the final paragraph of their "letter to the editor."

29 (I) Students watch a music video and are asked to describe how they feel about the lyrics and their interpretation of it.

33* (4) Students are writing fairy tales; teacher provides a writing frame and asks students to plan their writing; explicit focus is on typical features of traditional fairy tales and criteria for evaluating students' texts reflect these.

35* (I) Students have read a short story and must write a newspaper article based on the story's content, that is, students adapt content from one genre to another; teacher shows examples of how fiction can be described as if it were real using a "newspaper article" about Little Red Riding Hood and provides students with guidance on article structure and content. 
Table 2. (continued)

School and

(lesson)

Short description of writing assignment

35* (2) Students are writing science reports, graded jointly by teachers in science and Norwegian language arts; teacher explains how the science teacher will evaluate the scientific content, while she will evaluate whether the text is a report and to what degree it follows the report genre; the current writing assignment is to plan their report; teacher distributes a handout that students should fill in (with paragraphs/sentences, not keywords), encouraging them to use their books in science and social science (where they can read more about reports); teacher walks around the classroom offering individual guidance.

36* (I-2) Students have been reading novels of their own choice and must write a book report; students are given a structure they must follow; teacher models how to write a book report within this structure by writing a very short report on the board about a famous song and describes how students can use that step-by-step exercise when writing their own reports; during writing, teacher provides individual guidance.

37 (I-2) Students are revising a text they got from their teacher. There is explicit emphasis on improving the coherence between sentences, and making good transitions from one sentence to the next throughout the short text.

37 (4) Students keep working on the assignment described above (Lessons I-2). (They did not write in Lesson 3.)

38* (3-4) Students are writing in the genre "letter to the editor"; teacher provides very clear directions on content (e.g., how to start, one argument per paragraph, how to be convincing) and explicitly discusses the purpose of the genre; students may choose their own topic.

40* (4) As preparation to writing their own short story, students engage in specific plot-planning writing tasks, for example, writing detailed descriptions of important objects, main characters, how the story starts, and typical features of short stories they want to include in their own text

$4 I^{*}(I-2) \quad$ Students are working on writing their own "letter to the editor"; teacher scaffolds how different types of arguments can be used to debate the claim that students should have homework; teacher makes arguments available, but students can also choose to write about another topic in the same genre

44 (I) Students write stories - with a method labeled "circle writing" where they pass the text around in small groups and build on each other's sentences. 
Table 2. (continued)

School and

(lesson)

Short description of writing assignment

46* (4) Students have received written feedback from their teacher on their previously written letter to the editor, which they must now revise based on the teacher's comments; while revising, the teacher provides individual guidance, with an explicit focus on writing craft and genre.

$48(3)$

Drawing on a comic, students are asked to describe two characters, how they appear and how they behave, and how they change throughout the story.

$48(4)$

Still drawing on the comic, students are asked to write a story. They are supposed to keep the original plot from the comic, but to use words rather than drawings to convey what happens.

49 (I) The teacher reads a student text (sections of a fairy tale). The students revise the text, and are asked to improve it by adding more typical features of the fairy tale genre.

Lessons containing at least one segment scored 4 are marked with an asterisk.

Table 3. Overview of Writing Assignments in the 33 Lessons with Sustained Opportunities to Write.

\begin{tabular}{ll}
\hline Fiction (I5) & \multicolumn{1}{c}{ Nonfiction (I8) } \\
\hline Story (4) & Letter to the editor (7) \\
Description/show don't tell (7) & Article (3) \\
Short story (I) & Summary/annotation (I) \\
Fairy tale (2) & book report (2) \\
Write as if you were a 3-year-old (I) & Science report (I) \\
& Coordinating sentences in factual texts (2) \\
& Own reflections about music (I) \\
& News report (I) \\
\hline
\end{tabular}

produce during these lessons, and Table 3 summarizes what kind of texts students are writing.

As the tables suggest, a variety of genres, both fiction and nonfiction, are represented. Traditionally, LA teachers in Norway have given priority to writing fiction but this may - as our data indicate - be changing. Students represented in our data are producing multiparagraph texts across a variety of genres, both fiction and nonfiction.

Our qualitative analyses of the writing processes in these 33 lessons show that the teachers emphasize genre strongly, and they show a process-oriented 
approach to writing instruction. Further, teachers provide feedback both to individual students and in whole-class settings. These three key features are elaborated below.

Strong emphasis on genre. Even in lessons containing no writing, teachers may talk about genre and typical features of genres. Within a genre approach to writing, the "appropriacy" of a text is essential; the text has to meet the textual norms expected within the given genre and also be suitable for the purposes and contexts associated with the genre (Ivanič, 2004). When students are engaging in sustained writing, they are usually trying to meet the criteria or norms of a given genre, as presented by the teacher and often also the textbook. As Table 3 shows, most of the writing assignments are clearly framed within a named genre. We did not find teachers prompting students to mix genres, rather students were encouraged to demonstrate the typical features of the particular genre in their own writing. Often, students worked with the specific genre extensively before they got a chance to write something. In School 38, for example, students worked with argumentative essays. Before writing, the teacher put a strong emphasis on what is typical within this genre; when talking to students about the genre, the main purpose of writing argumentative texts is also emphasized:

Teacher (School 38): Remember that when you are writing argumentative essays you can use arguments. And what else do you have to remember? What else is it that you have to remember with the arguments you use? We said before that you have to stay on topic, but ... yes?

Student: Maybe not use childish arguments?

Teacher: Yes.

Student: Or maybe not use humor.

Teacher: No. And those who are fond of using humor [should] save their humor for another genre. You can use humor. It's not that you can't, but it has to be focused and stick to the topic. You become more believable then, and the reader trusts you more. Also, the more you provide justifications, the better the argument. So don't just throw out a claim and a sentence, but try to provide several reasons because then your arguments become stronger and more believable. Then it is easier for you to influence the reader.

In this example from School 38, the teacher makes a connection between the purpose of writing in this context ("influence the reader") and the overall genre ("argumentative essays"), and arguments are framed as an essential feature of argumentative texts. A similar example concerning fiction writing 
is from School 40. This is the previously mentioned class where students were told to describe an object in detail (like the student text in Figures 6 and 7). In the next lesson, the teacher asked them to write a short story, using their object and the descriptions of it, combined with their knowledge of short story as a genre:

Teacher (School 40): I want you to try to keep in mind the short story genre that we have worked with lately. So then you have to think about how you are going to start. A short story often starts in the middle of the plot, in medias res, right on. So that could be a possibility. And then you have to think about how you are going to foreground the object in the plot. Is it going to be a symbol of something, or is it going to be a tool you are going to use, or that the main character will use, in this story? So think about it in that way.

This way of framing the writing within a particular genre is quite typical across our collected material. While students may work with smaller writing assignments with no specific genre criteria, we have not identified any sustained writing opportunities where the students write longer texts for assessment without a specified genre. As the following short examples illustrate, some students are provided with opportunities to write long texts during their LA lessons. These examples of long texts are from School 26. In the previous lesson (which took place before we began videotaping), the students had been given the following instruction: "Write a story titled 'The Attic.' Use your senses and describe the objects that you see, the atmosphere, the sounds and smells. Try to write in present tense and remember to use adjectives." Two of the student texts are in Figures 9a and 9b.

We use these texts as illustrations of how the students write longer texts and also how they clearly work with a particular way of writing descriptions and using specific features of a genre. Here, the teacher even prompts the students to include adjectives in their descriptions.

Strong emphasis on process-oriented writing. It is evident in our material that teachers usually take a process-oriented approach when asking students to write longer texts. Across lessons in which students are writing multiparagraph texts, they are also engaging in discussions about model texts within that genre, planning texts, revising drafts, commenting on specific text features in whole-class discussions, and so on. This is evident in some of the examples already shared (see Figures 5-7, which later resulted in a sustained opportunity to write a fairy tale). Another typical process-oriented example is from School 13. Students were going to write stories, and the teacher clearly divided the writing process into steps: 


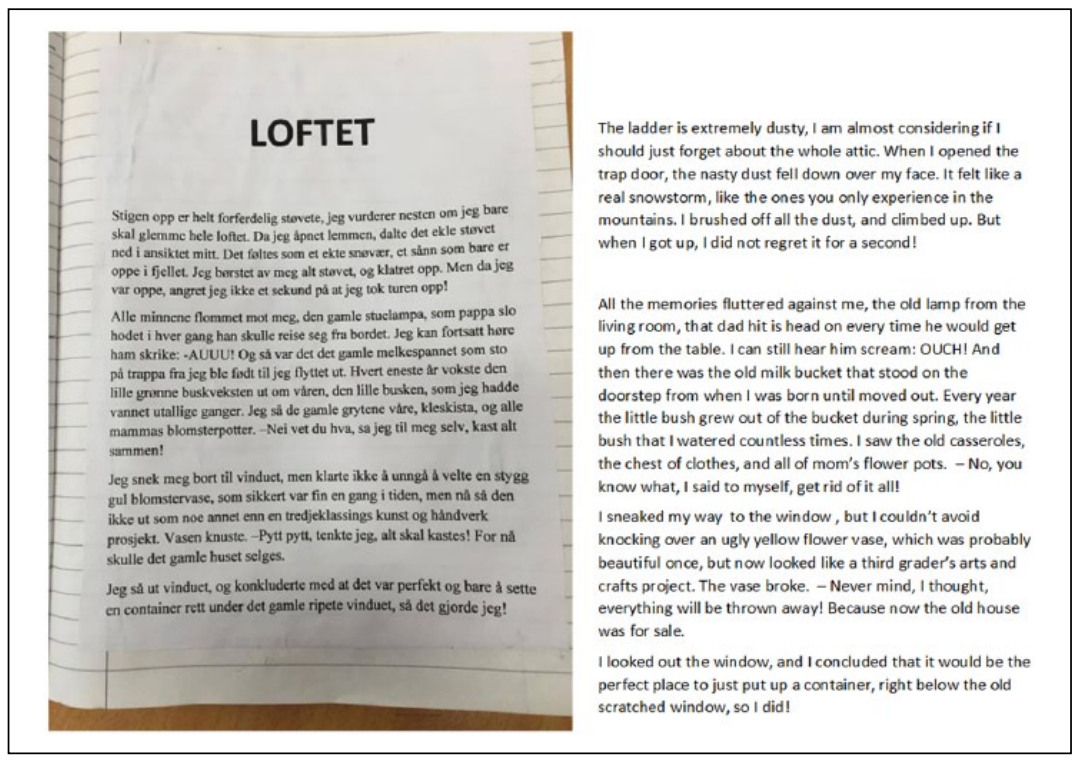

Figure 9a. Sustained writing-“The Attic” I.

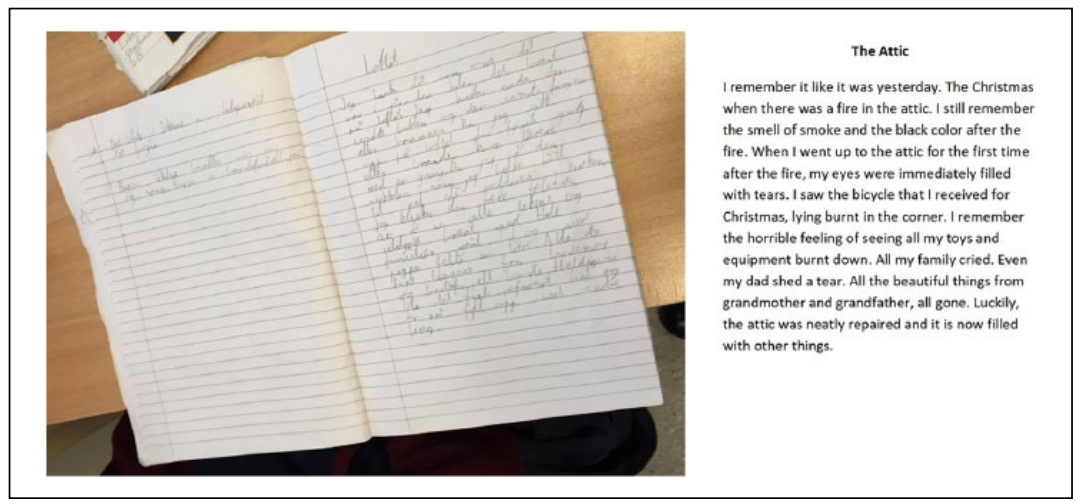

Figure 9b. Sustained writing—“The Attic” 2.

Teacher (School 13): So, the aim of this lesson is that you are going to figure out what you are going to write about, and then we will try to write an introduction before we leave today. The first thing we are going to do is that we will go through the writing assignment, which some of you have gotten already 
and some will get today. Then you will fill in the "content star," which you already know. And then when you have filled it in, I want you to raise your hand and I will come and give you some feedback on whether it is going to work with the assignment you have chosen. Then, if you get a "Go for it, this sounds great!," start writing the story.

The "content star" the teacher referred to is a graphic organizer students have used to plan the main plot of their story. It is referred to as a known resource. Further, this teacher wanted to talk to all students about their writing before they actually began writing their introduction, which means these students received feedback as early as the planning stage.

Revising text is another important part of a process-oriented approach to writing. Some teachers in our material talked about revising and its importance, and some, like the teacher in School 27, gave the students an opportunity to revise their short articles in class:

Teacher (School 27): If some of you are done you may start on a draft for a new article, or you may shorten the one you have and work on condensing it. And maybe have a look at the language you have used, see if there is room for improvement. Because if you have written a text only once, it is not supposed to be good enough. Then there is something wrong. A draft, something you have written once, has to have some possibilities for changes and looking at repetitions and transitions. Take a look at how you have written this text. Shall we say ten minutes? That is enough? Ok. Raise your hand if you have any questions.

Here, as in many other writing lessons, the teacher circulates, assisting students while they are engaged in writing. This is an important part of processoriented writing instruction, and it is a prominent feature across the 33 lessons with sustained writing, as elaborated in the following.

Feedback while writing. Across the writing activities listed in Table 2, teachers allowed students to write for sustained periods and often walked around in the classroom, reading individual students' texts and discussing the students' writing. During these conversations, the teacher was often able to focus students' attention on issues of writing craft, style, or genre. One example, from School 28, illustrates this well: The class worked on argumentative essays over several lessons. Students had ample opportunity to write, and the teacher walked around, read each student's text upon request, and provided individual guidance. The following conversation took place after a student (Ane) asked a very common question, namely, how long her essay should be: 
Teacher (School 28): How long it should be? I think you should have one page. So this is almost that, so you still have some [writing] left to do. What do you think?

Student: I don't know, I don't have anything else to write.

Teacher: No? Then I will read it.

[teacher reads Ane's text]

Teacher: Ok, well, here you have an argument: [reads from student text] "Many grownups believe that school uniforms lead to less bullying, but the experts say. ..." Try to be a bit personal. Here, you can elaborate and say ... "I have never been bullied for the clothes I wear. I have never seen anything. I don't think there actually is much bullying due to clothes." Do you understand? You have used a lot of "other people have said," but what do you think? I do not hear Ane's voice. So a little there [points to the text], and there. But it is very good that you had that argument.

As this example illustrates, the teacher provides concrete suggestions for improving the student's work and urges a more personal tone in the persuasive essay. Her advice is not general; it is directly connected to content in Ane's text. Conversations such as this were common in the 33 lessons in which teachers gave students time to write. Several teachers also arranged for students to comment on each other's drafts, which aligns well with the process-oriented writing emphasis outlined above.

\section{Discussion}

Research on writing instruction has shown that there is considerable variability in how writing is taught both within and across countries (Graham \& Rijlaarsdam, 2016) and that the amount of time students get to compose text varies greatly. While Purves's (1992) study from the early 1990s showed how American students often produced a single version of a text in a relatively short time, while, for example, Italian and Finnish students typically wrote several drafts, recent studies show how process-oriented approaches to writing have been embraced in American classrooms (Cutler \& Graham, 2008; Graham \& Sandmel, 2011).

Our study shows how writing appears to serve two main functions in Norwegian LA classrooms. First, we identified a range of smaller writing tasks that are used to document students' learning, such as using writing to answer questions, make mind maps, or show knowledge through a variety of graphic organizers. Here, the main emphasis is on content knowledge rather than helping students improve as writers. However, we also identified that 
even in situations coded as limited opportunities to write (scoring 2 in PLATO), teachers still engaged students in smaller, targeted writing activities to improve their writing in specific styles or aspects of genres, often in order to engage them in sustained writing tasks in the next few lessons. Further, we identified that in more than half of the 46 classrooms we visited for four consecutive lessons, students were given at least one opportunity to engage in sustained writing.

The one repeated activity we identified across classrooms exhibiting fragmented writing without any clear purpose is student note taking. As previously mentioned, when students take notes, we find a tendency to merely recopy information from the board, and thus this writing cannot be seen as demonstrating content knowledge. One could even discuss if this passive writing should be referred to as "note taking." The question of why students need to recopy information remains unanswered across classrooms. Although we could infer that transportability and possibility to look at the notes later are a potential reason, the information students are copying very often is available through the teachers' PowerPoints on a digital learning platform. We find it interesting that the students themselves are often the ones asking "Should we be writing this down?" The teacher then initiates the note-taking sessions, slowing the entire lesson. In these situations, the purpose of writing is often difficult to discern. Taking notes can be a demanding task, one that ideally involves a student actively selecting key ideas to write down because they appear relevant. Based on our findings, we thus believe that students should learn techniques for annotation and note taking in school and could benefit from more explicit focus on what good notes are, what purposes note taking can have, how writing is related to learning, and how to think analytically to produce useful notes.

A key finding of this study is that sustained writing opportunities are often framed within a process-oriented and genre-specific writing discourse (Ivanič, 2004), wherein the teacher emphasizes how and why to write in specific ways. During these lessons, we have found that teachers often provide scaffolding, for example, through "writing frames" (showing different components of a text) that are discussed verbally with the whole class, and teachers often discuss how students' writing will be assessed. While some teachers let students talk to each other and discuss each other's texts based on specific criteria, other teachers discuss different students' texts in whole-class settings and highlight the implications of different ways of writing - for example by discussing the implications of specific word choices, or how the writing style will affect the reader. We are positively surprised by the amount of scaffolding and the emphasis on purpose in many of the sustained writing activities. In stark contrast to many of the studies reviewed above, we find that when 
Norwegian LA teachers prioritize writing, the opportunities to write are both sustained and scaffolded, the purpose of writing is explicit, and genre-specific assessment criteria are often used. Remarkably, in our study students are either engaging in very clear writing activities with explicit purposes for writing, or they are engaging in activities where writing is merely a way of showing content knowledge, a way to document and communicate what the students know about a given topic. There is little middle ground here. In other words, teachers in our study either provide very clear and systematic writing opportunities with emphasis on genre, purpose and process, or provide tasks where the writing is implicit, and in these cases they pay no attention to writing style, genre, or craft.

Our study also provides valuable insight into what happens when teachers walk around classrooms talking to individual students about their texts. Examples presented herein show how teachers are able to provide individualized guidance directly targeting the specific student's text while the text is still being written. This is a unique opportunity to provide useful feedback, and as Igland (2009) also shows, scaffolding provided by a teacher can be crucial for developing writers. Opportunities to write are a prerequisite for good writing development, but the quality of the opportunity also matter, and here the teacher has a key role. In our study we see several examples of students struggling with a particular part of the writing process, and how the teachers are able to establish a conversation with the student where they talk about different ways of solving the issue in question. Often this involves the teacher reading the students' text, asking questions and making suggestions.

Another important finding concerns the status of nonfiction writing. Norwegian students have traditionally written personal, subjective narratives more often than nonfiction; this is seen in relation to LA subjects that have also prioritized literary genres over, for example, reflective essays or argumentative texts. However, since the introduction of the new curriculum in 2006, increasing attention has been paid to writing in the Norwegian curriculum in general (Krogh et al., 2017), and in LA, fiction and nonfiction are explicitly treated as equally important. Interest is growing in writing across subjects and argumentative writing, and the writing exams are changing; all students must now master nonfiction writing. Our data, which show that many writing lessons are devoted to argumentative writing, strengthen and illustrate the general perception that there has been a shift from literary genres to factual prose in LA. Although we have highlighted several student examples from literary genres in our analyses, we also found that students are engaging in writing of nonfiction. As shown in Table 2, there are several writing assignments revolving around nonfiction, and the two most frequent 
genres in our material are letter to the editor (nonfiction) and different ways of expanding the moment/show don' tell (often used in fiction).

We found that when students in our study have the opportunity to write, the writing instruction provided is of high quality and aligns with recommendations from writing research. The opportunity to write, in itself, is not necessarily a guarantee for good writing instruction, but in our data there is a clear relationship between teachers who give priority to students' writing in class and teachers who provide high-quality writing instruction, with scaffolding and feedback embedded in the lesson. The big question, then, is whether students have enough meaningful opportunities to write in class, within clearly framed writing tasks and with the guidance and feedback of a teacher. We would not expect the complex teaching of LA as a subject to focus only on writing, and it would be equally unreasonable to expect teachers to provide ample writing opportunities in every lesson. It is hard for us to state strongly that "students should be writing more than this." Yet, an important argument we draw from our study is that when teachers prioritize writing instruction, they are able to provide high-quality, varied, and scaffolded instruction, in line with evidence-based best practices for writing, with clear purposes and assessment criteria related to genre. These teachers are also able to provide crucial individual guidance. While opportunities to write do not guarantee good writing instruction, we do find that opportunities to write for a sustained period of time are a prerequisite for scaffolded instruction and individual feedback on writing in class. In other words, we do not find high-quality feedback on student texts or explicit scaffolding practices targeting writing in lessons where students are not provided with sustained writing opportunities. Given this finding, it is tempting to say that teachers should explicitly decide "this is a writing lesson" more often.

\section{Acknowledgments}

The authors would like to thank Professor Frøydis Hertzberg for very useful comments on an early draft of this article. We would also like to thank the three anonymous reviewers for their encouraging remarks and valuable advice. Finally, we thank our research team on the LISA-study (Linking Instruction and Student Achievement), including our research assistant Kjetil Birkeland, for all good discussions about writing instruction.

\section{Declaration of Conflicting Interests}

The authors declared no potential conflicts of interest with respect to the research, authorship, and/or publication of this article. 


\section{Funding}

The authors received no financial support for the research, authorship, and/or publication of this article.

\section{Notes}

1. For more on the research design itself, see Klette, Blikstad-Balas, and Roe (2017).

2. Eight of these 33 lessons are "double" lessons with two lessons in LA happening right after each other (often without a break between the $45+45$ minutes), but they are here counted as one lesson because students typically work with the same writing task for both lessons.

\section{References}

Alvermann, D. E. (2009). Sociocultural constructions of adolescence and young people's literacies. In L. Christenbury, R. Bomer, \& P. Smagorinsky (Eds.), Handbook of adolescent literacy research (pp. 14-28). New York, NY: Guilford.

Applebee, A. N. (1984). Contexts for learning to write: Studies of secondary school instruction. Writing research: Multidisciplinary inquiries into the nature of writing series. Stanford, CA: ERIC.

Applebee, A. N., \& Langer, J. A. (2006). The state of writing instruction in America's schools: What existing data tell us. Albany, NY: Center on English Learning and Achievement.

Applebee, A. N., \& Langer, J. A. (2009). What is happening in the teaching of writing? English Journal, 98(5), 18-28.

Applebee, A. N., \& Langer, J. A. (2011a). "EJ" extra: A snapshot of writing instruction in middle schools and high schools. English Journal, 100(6), 14-27.

Applebee, A. N., \& Langer, J. A. (2011b). The national study of writing instruction: Methods and procedures. Albany, NY: Center on English Learning and Achievement.

Barton, D. (1991). The social nature of writing. In R. Ivanič \& D. Barton (Eds.), Writing in the community (pp. 1-13). London, UK: Sage.

Barton, D. (2007). Literacy: An introduction to the ecology of written language. Malden, MA: Blackwell.

Bazerman, C. (2016). What do sociocultural studies of writing tell us about learning to write? In C. A. MacArthur, S. Graham, \& J. Fitzgerald (Eds.), Handbook of writing research (Vol. 2, pp. 11-25). New York, NY: Guilford.

Beaufort, A. (2008). Writing in the professions. In C. Bazerman (Ed.), Handbook of research on writing: History, society, school, individual, text (pp. 221-235). Mahwah, NJ: Lawrence Erlbaum.

Berge, K. L., \& Skar, G. (2015). Ble elevene bedre skrivere. Intervensjonseffekter på elevers skriveferdigheter og skriveutvikling [Did the students become better writers. An intervention on students writing skills and writing development] (Report 2 from the Project Developing National Standards for the Assessment 
of Writing. A Tool for Teaching and Learning). Trondheim, Norway: Høgskolen I Sør Trøndelag. Retrieved from http:/www.uio.no/studier/emner/uv/ils/ PPU3220/h16/ble-elevene-bedre-skrivere.pdf

Blikstad-Balas, M. (2012). Digital literacy in upper secondary school-what do students use their laptops for during teacher instruction? Nordic Journal of Digital Literacy, 7(2), 81-96.

Blikstad-Balas, M. (2017). Key challenges of using video when investigating social practices in education: Contextualization, magnification, and representation. International Journal of Research \& Method in Education, 40(5), 511-523.

Blikstad-Balas, M., \& Sørvik, G. O. (2015). Researching literacy in context: Using video analysis to explore school literacies. Literacy, 49(3), 140-148.

Boscolo, P., \& Carotti, L. (2003). Does writing contribute to improving high school students' approach to literature? L1-Educational Studies in Language and Literature, 3(3), 197-224.

Boscolo, P., \& Hidi, S. (2007). The multiple meanings of motivation to write. In G. Rijlaarsdam (Series Ed.),P. Boscolo \& S. Hidi (Volume Eds.), Studies in writing: Writing and motivation (Vol. 19, pp. 1-14). Oxford, UK: Elsevier.

Brevik, Lisbeth M., Blikstad-Balas, Marte \& Engelien \& Kirsti Lyngvær (2017). Integrating assessment for learning in the teacher education programme at the University of Oslo. Assessment in education: Principles, Policy \& Practice. ISSN 0969-594X. 24(2), s 164-184.

Brevik, Lisbeth M. (2017). Strategies and shoes: Can we ever have enough? Teaching and using reading comprehension strategies in general and vocational programmes. Scandinavian Journal of Educational Research. ISSN 0031-3831. 61(1), s 76-94.

Brockmeier, J., \& Olson, D. (2009). The literacy episteme. From Innis to Derrida. In D. R. Olson \& N. Torrance (Eds.), Cambridge handbook of literacy (pp. 3-22). New York, NY: Cambridge University Press.

Cohen, J., \& Grossman, P. (2016). Respecting complexity in measures of teaching: Keeping students and schools in focus. Teaching and Teacher Education, 55, 308-317.

Cutler, L., \& Graham, S. (2008). Primary grade writing instruction: A national survey. Journal of Educational Psychology, 100(4), 907-919.

Dockrell, J. (2009). Causes of delays and difficulties in the production of written text. In R. Beard, D. Myhill, J. Riley, \& M. Nystrand (Eds.), The Sage handbook of writing development (pp. 489-505). Thousand Oaks, CA: Sage.

Gadd, M., \& Parr, J. M. (2017). Practices of effective writing teachers. Reading and Writing, 30(7), 1551-1574.

Gamlem, S. M. (2017). Læreres tilbakemeldinger i klasserommet [Teachers' feedback in the classroom]. In K. Lyngsnes \& M. Rismark (Eds.), Didaktisk praksis 5-10 [Didactic practice 5th-10th stage] (pp. 171-190). Oslo, Norway: Gyldendal Akademisk Forlag.

Gee, J. P. (2015). Literacy and education. New York, NY: Routledge.

Gillespie, A., Graham, S., Kiuhara, S., \& Hebert, M. (2014). High school teachers' use of writing to support students' learning: A national survey. Reading and Writing, 27(6), 1043-1072. 
Graham, S., Harris, K. R., \& Chambers, A. B. (2016). Evidence-based practice and writing instruction: A review of reviews. In C. A. MacArthur, S. Graham, \& J. Fitzgerald (Eds.), Handbook of writing research (Vol. 2, pp. 211-226). New York, NY: Guilford.

Graham, S., \& Perin, D. (2007). Writing next: Effective strategies to improve writing of adolescents in middle and high schools. A report to Carnegie Corporation of New York. Washington, DC: Alliance for Excellent Education.

Graham, S., \& Rijlaarsdam, G. (2016). Writing education across the globe: Introduction and call for a new global analysis. Reading and Writing, 29(5), 781-792.

Graham, S., \& Sandmel, K. (2011). The process writing approach: A meta-analysis. Journal of Educational Research, 104(6), 396-407.

Grossman, P. (2010). The Plato protocol for classroom observations. Seattle, WA: Bill \& Melinda Gates Foundation.

Grossman, P., Loeb, S., Cohen, J., \& Wyckoff, J. (2013). Measure for measure: The relationship between measures of instructional practice in middle school English language arts and teachers' value-added scores. American Journal of Education, 119(3), 445-470.

Hassan, X., Macaro, E., Mason, D., Nye, G., Smith, P., \& Vanderplank, R. (2005). Strategy training in language learning-A systematic review of available research. London, UK: EPPI-Centre, Social Science Research Unit, Institute of Education, University of London.

Heath, C., Hindmarsh, J., \& Luff, P. (2010). Video in qualitative research: Analysing social interaction in everyday life. London, UK: Sage.

Hertzberg, F., \& Dysthe, O. (2012). Prosesskriving-hvor står vi i dag? [Processoriented writing - Where do we stand today?] In S. Matre, D. Kibsgaard Sjøhelle, \& R. Solheim (Eds.), Teorier om tekst i møte med skolens lese-og skrivepraksiser [Theories of text in meeting the school's reading and writing practices] (pp. 59-71). Oslo, Norway: Universitetsforlaget.

Hertzberg, F., \& Roe, A. (2015). Writing in the content areas: A Norwegian case study. Reading and Writing, 29(3), 555-576.

Hull, G., \& Schultz, K. (2001). Literacy and learning out of school: A review of theory and research. Review of Educational Research, 71(4), 575-611.

Igland, M.-A. (2009). Negotiating problems of written argumentation. Argumentation, 23(4), 495-511.

Ivanič, R. (2004). Discourses of writing and learning to write. Language and Education, 18(3), 220-245.

Jensen, C. (2016). "Nå skal vi gjøre noe kjekt"-Loreres bruk av prosesskriving på ungdomstrinnet ["Now we are going to do something nice"-Teachers use of process writing in lower secondary school] (Master's thesis). University of Oslo, Oslo, Norway.

Jensen, L. V. (2016). Hvor ble det av sjangrene? Lareres undervisning i teksters form og funksjon på 8.trinn [Where did the genes go? Teachers instruction on textual form and function in the eighth grade] (Master's thesis). University of Oslo, Oslo, Norway. 
Johannessen, L. R., \& McCann, T. M. (2009). Adolescents who struggle with literacy. In L. Christenbury, R. Bomer, \& P. Smagorinsky (Eds.), Handbook of adolescent literacy research (pp. 65-79). New York, NY: Guilford.

Joly, N. (2010). Tracing cows: Practical and administrative logics in tension? In D. Barton \& U. Papen (Eds.), The anthropology of writing: Understanding textually mediated worlds (pp. 90-105). London, UK: Continuum.

Kaminski, R., Hunt-Barron, S., Hawkins, D., \& Williams, H. (2010). Evaluating project WRITE: Determining the impact of a professional development program focusing on a writing workshop approach and the traits of quality writing. Retrieved from https://www.nwp.org/cs/public/print/resource/3718

Karlsson, A.-M. (2009). Positioned by reading and writing literacy practices, roles, and genres in common occupations. Written Communication, 26(1), 53-76.

Kiuhara, S. A., Graham, S., \& Hawken, L. S. (2009). Teaching writing to high school students: A national survey. Journal of Educational Psychology, 101(1), 136-160.

Klette, K. (2009). Challenges in strategies for complexity reduction in video studies. Experiences from the PISA+ study. In T. Janik \& T. Seidel (Eds.), The power of video studies in investigating teaching and learning in the classroom (pp. 61-83). Münster, Germany: Waxmann.

Klette, K., \& Blikstad-Balas, M. (2017). Observation manuals as lenses to classroom teaching: Pitfalls and possibilities. European Educational Research Journal. Advance online publication. doi:10.1177/1474904117703228

Klette, K., Blikstad-Balas, M., \& Roe, A. (2017). Linking instruction and student achievement: Research design for a new generation of classroom studies. Acta Didactica Norge, 11(3), 19.

Krogh, E., Dysthe, O., Hertzberg, F., \& Brorsson, B. N. (2017). Writing in the content areas. A Scandinavian perspective combining macro, meso, and micro levels. In S. Plane, C. Bazerman, F. Rondelli, C. Donahue, A. N. Applebee, C. Boré, ... D. Russell (Eds.), Research on writing: Multiple perspectives. Fort Collins, CO: WAC Clearinghouse.

Kwok, M. N., Ganding, E., III, Hull, G. A., \& Moje, E. B. (2016). Sociocultural approaches to high school writing instruction. Examining the roles of context, positionality, and power. In C. A. MacArthur, S. Graham, \& J. Fitzgerald (Eds.), Handbook of writing research (Vol. 2, pp. 257-271). New York, NY: Guilford.

Langer, J. (2009). Contexts for adolescent literacy. In L. Christenbury, R. Bomer, \& P. Smagorinsky (Eds.), Handbook of adolescent literacy research (pp. 49-64). New York, NY: Guilford.

MacArthur, C. A., Graham, S., \& Fitzgerald, J. (2016). Introduction. In C. A. MacArthur, S. Graham, \& J. Fitzgerald (Eds.), Handbook of writing research (pp. 1-7). New York, NY: Guilford.

MacGillivray, L., \& Curwen, M. S. (2007). Tagging as a social literacy practice. Journal of Adolescent \& Adult Literacy, 50(5), 354-369.

Matre, S., \& Solheim, R. (2015). Writing education and assessment in Norway: Towards shared understanding, shared language and shared responsibility. L1-Educational Studies in Language and Literature, 15, 1-22. 
Mikulecky, L. (1998). Adjusting school writing curricula to reflect expanded workplace writing. In M. S. Garay \& S. A. Bernhardt (Eds.), Expanding literacies: English teaching and the new workplace (pp. 201-223). Albany: State University of New York Press.

Olson, D. R. (2008). History of schools and writing. In C. Bazerman (Ed.), Handbook of research on writing. History, society, school, individual, text (pp. 283-292). New York \& London: Lawrence Erlbaum Associates.

Ongstad, S. (2002). Positioning early research on writing in Norway. Written Communication, 19(3), 345-381.

Purves, A. C. (1992). Reflections on research and assessment in written composition. Research in the Teaching of English, 42, 104-120.

Roe, A., \& Helstad, K. (2014). Den andre skriveopplæringen i Norge-om prosesskriving og skriving i og på tvers av fag [The secondary writing instruction in Norway - On process-oriented writing across subjects]. In R. E. Hvistendahl \& A. Roe (Eds.), Alle tiders norskdidaktiker (pp. 171-193). Oslo, Norway: Novus Forlag.

Smagorinsky, P., \& Mayer, R. E. (2014). Learning to be literate. In K. Sawyer (Ed.), The Cambridge handbook of the learning sciences (pp. 605-625). Cambridge, UK: Cambridge University Press.

Smagorinsky, P., \& Smith, M. W. (1992). The nature of knowledge in composition and literary understanding: The question of specificity. Review of Educational Research, 62(3), 279-305.

Smidt, J. (2007). Positioning, responsibility, and relevance in MTE research. In W. Herrlitz, S. V. Ongstad, \& van de V. Piet-Hein (Eds.), Research on mother tongue education in a comparative international perspective: Theoretical and methodological issues (pp. 211-226). Amsterdam, Netherlands: Rodopi.

Smidt, J. (2010). Skriving i alle fag: innsyn og utspill [Writing in all subjects-book]. Trondheim, Norway: Tapir akademisk forlag.

Snell, J. (2011). Interrogating video data: Systematic quantitative analysis versus micro-ethnographic analysis. International Journal of Social Research Methodology, 14(3), 253-258.

UNESCO. (2004). The plurality of literacy and its implications for policies and programs: Position paper (Vol. 13). Paris, France: United National Educational, Scientific and Cultural Organization.

Wade, S. E., \& Moje, E. B. (2000). The role of text in classroom learning. In M. L. Kamil, P. B. Mosenthal, D. B. Pearson, \& R. Barr (Eds.), Handbook of reading research (Vol. 3, pp. 609-627). Mahwah, NJ: Lawrence Erlbaum.

Yi, Y. (2010). Adolescent multilingual writers' transitions across in- and out-ofschool writing contexts. Journal of Second Language Writing, 19(1), 17-32.

\section{Author Biographies}

Marte Blikstad-Balas is an Associate Professor at the Department of Education and School Research, University of Oslo. Her research interests are literacy and how texts are used in school across subjects. 
Astrid Roe is a Professor at the Department of Education and School Research, University of Oslo. Her research interests are reading and writing. For instance, she has investigated how writing is being taugh in the content areas.

Kirsti Klette is a Professor at the Department of Education and School Research, University of Oslo. Her research interests are classroom research and methodological issues tied to how instructional quality can be systematically investigated. 